\title{
Transformácia či zánik? Vývoj odborov v Slovenskom štáte (1939-1945) v kontexte vybraných európskych diktatúr
}

\section{Transformation or extirpation? Development of trade unions in the Slovak state (1939-1945) in the context of selected European dictatorships}

\author{
Adam Šumichrast / sumichrast.a@mail.muni.cz \\ Historický ústav, Filozofická fakulta, Masarykova univerzita, Brno, CZ
}

\begin{abstract}
The emergence of the Slovak state in 1939 constituted a fundamental change which affected all areas of society, including trade unions. The paper aims to answer the question whether the changes that the Slovak trade union movement has affected can be described as its transformation or rather the extinction. By its very nature, the Slovak state was heavily influenced by foreign countries, especially Nazi Germany. At some stage in the development of the regime, however, he sought inspiration even in fascist Italy. Subsequently these patterns embraced in their political and organizational practice. For this reason, the study will also deal with trade union status in Germany and Italy. In the comparative context, the paper will also examine which types of foreign patterns have been taken over in Slovakia, who was their originator, and what were the activities of the trade unions in the Ludak regime?
\end{abstract}

\section{Keywords}

Trade Unions; Corporatism; Nazism; Fascism; Totalitarianism; Slovak State 


\section{Úvod}

Fašizmus ako nová ideológia, implementovaná do talianskeho politického systému v prvej polovici 20. storočia, patril medzi najvýznamnejšie fenomény svojej doby. ${ }^{1} \mathrm{Z}$ Apeninského polostrova sa jeho myšlienky a politická prax, ktoré boli úzko prepojené s ideou korporativizmu (ako istou ekonomickou praxou fašizmu), dostali aj do širšieho povedomia a fungovania európskej spoločnosti. ${ }^{2}$ Medzivojnové obdobie a roky druhej svetovej vojny boli charakteristické zánikom demokracií a vznikom rôznych foriem diktatúr, čo ovplyvnilo transformáciu mnohých inštitúcií v spoločnosti. Rôzne formy diktatúr zasiahli až 29 štátov. V roku 1920 mali okrem troch európskych krajín všetky ostatné také štátne zriadenie, ktoré možno považovat za demokratické (parlamentný systém s volenými vládami, rôznorodá škála politických strán a garantované individuálne slobody). Avšak, už pred vypuknutím druhej svetovej vojny, malo najmenej 16 krajín diktátorský charakter, pričom na konci roku 1940 zostalo v európskom priestore fungovat iba pät demokracií. ${ }^{3}$ Nástup diktatúr významne ovplyvnil aj fungovanie odborov. Novo etablovaný politický systém mohol v závislosti od svojho charakteru vplývat na fungovanie a pozíciu odborov v jednotlivých prípadoch odlišne. V mnou vymedzenej téme tak vyvstáva otázka, nakol’ko išlo o premenu alebo o úplnú zmenu odborov v Slovenskom štáte.

Pokúsim sa odpovedat na otázky v akom ideovom prostredí fungovali a akú činnost' vyvíjali odbory v Slovenskom štáte v rokoch 1939-1945. Poukážem na medzinárodný kontext, v ktorom bolo pre slovenské reálie klúčové dianie vo fašistickom Taliansku a nacistickom Nemecku. Predstavitelia Slovenského štátu recipovali, aj vzhladom na jeho vazalský charakter, postupy práve z týchto krajín. Zaujímat ma bude, aké konkrétne zahraničné aspekty a mechanizmy fungovania z odborového prostredia sa aplikovali v slovenských reáliách. Dochádzalo k nejakým kontradikciám medzi vplyvmi z daných krajín?

V práci využijem prístup historickej komparácie nazvaný „paralelná demonštrácia teórie," ktorý zadefinovali autorky Theda Skocpol a Margaret Sommers. Ten môže preukázat’ význam, ked’ sa aplikuje na reálne historické prípady, pričom sa predpokladá hladanie podobností v skúmaných prípadoch. Pred samotným opisom historických prípadov sa predstaví teoretický model alebo hypotéza, ktoré sa následne komparáciou overia alebo vyvrátia. ${ }^{4} \mathrm{~V}$ mojom prípade sa čiastočne inšpirujem aj teóriou totalitarizmu.

1 Pozri Drábik, Jakub: K problematike definície pojmu fašizmus, „nového konsenzu“ a vývoja v bádani o fašizme. Historický časopis 62, 2014, s. 709.

2 Costa Pinto, Antonio: The corporatist wave - corporatism and the diffusion of „organic representation “ in European dictatorships. Lisabon 2016, s. 3-5. Pojem korporativizmus odvodzujeme od slova korporácia, ktorá predstavuje spoločnú organizáciu pracujúcich a zamestnávatelov v rovnakej sfére. Korporatívna organizácia reprezentuje oficiálne „spoločné“ záujmy. Vo všeobecnosti možno hovorit’ o systéme sociálnej a politickej organizácie (z toho vyplýva aj delenie na sociálny a politický korporativizmus), v ktorom sú hlavné spoločenské skupiny a záujmy (práca, obchod, pol’nohospodárstvo, armáda, náboženstvo a i.) integrované do monopolistického vládneho systému. Pozri O’Sullivan, Noel: Fašismus. Brno 2002, s. 6.

3 Vel'ká Británia, Írsko, Švédsko, Fínsko a Švajčiarsko. Pozri Vilar-Rodríguez, Margarita: „The labour market under the iron fist of the state": the Franco dictatorship in the mirror of Hitler, Mussolini and Stalin. European Review of History: Revue européenne d'histoire 20, 2013, s. 427.

4 Skocpol, Theda - Somers, Margaret: The Uses of Comparative History in Macrosocial Inquiry. Comparative 
O totalitnom režime nebudem uvažovat normatívne či ideologicky, ${ }^{5}$ ale v zmysle analógovej škály, ktorej dva póly predstavujú ideálne typy (demokracia $\longleftrightarrow$ totalita), ku ktorým sa možno v politickej realite len približovat. ${ }^{6}$ Totalitarizmus predstavuje snahu o úplné ovládnutie všetkých aspektov spoločnosti štátom. Klasická práca Carla Joachima Friedricha a Zbigniewa Brzezinskeho určuje šest’ základných šest’ bodov, ktoré sú charakterizujúce pre totalitný režim. ${ }^{7}$ Tendenciu ideologizovat a monopolizovat celú spoločnost', čoho vplyvom zanikajú autonómne subsystémy, ako základný rys totalitarizmu spomína Juan Linz. Tento prvok sa spája aj s masovou politickou a sociálnou mobilizáciou, ktorou sa režim snaží aktivizovat' l'udí pre svoje ciele. ${ }^{8}$ Demokratický ideál možno pre zjednodušenie chápat ako negáciu spomenutých prvkov a snáh totalitného režimu. ${ }^{9}$

Diktátorské režimy neboli statické, ale naopak vnútorne dynamické. Ich posun na vymedzenej škále predstavuje možnost̉ vymedzovat rôzne špecifické typy režimov. ${ }^{10} \mathrm{~V}$ príspevku sa zameriam na vývojové trendy režimu a z nich vyplývajúci vplyv na fungovanie odborov. ${ }^{11}$ Odbory možno charakterizovat ako "kontinuálnu asociáciu námezdne zarábajúcich, ktorá koná v zmysle dosahovania alebo zlepšovania podmienok pre ich pracovné životy."12 Moja hypotéza spočíva v tom, že ak sa dynamika režimu posúva smerom k pólu totality, dochádza k obmedzovaniu a redukcii reálnej činnosti odborov a transformuje sa ich charakter, resp. úplne zanikajú. Potenciálne môže dôjst̉ ku vzniku novej organizácie, ktorá síce takisto združuje námezdne pracujúcich, ale už za účelom pacifikácie ich organizovaných záujmov, udržania sociálneho zmieru a všeobecného ideologického pôsobenia v prospech ekonomických záujmov režimu.

Studies in Society and History 22, 1980, s. 176-178. Za inklináciou ku komparatívnej perspektíve je aj snaha prekonat mantinely národného štátu a koncept „metodologických nacionalistov.“ V kontexte „Global Labor History“ je zrejmé, že vývoj v jednotlivých národných štátoch bol určovaný aj vplyvmi a impulzmi zo zahraničia. Pozri Linden, Marcel, Van Der: Workers of the World. Essays toward a Global Labor History. Leiden - Boston 2008, s. 7-8.

5 Paradigma totalitarizmu získala v 50. rokoch 20. st. v západnom akademickom prostredí vel'ký ohlas. V 60. a 70. rokoch bola zase spochybňovaná kvôli jej politickému podtónu. Po páde sovietskeho bloku vznikol nový prístup, ktorý vyzdvihuje kognitívny prínos (pripadne nedostatky) teórie totalitarizmu a abstrahuje ich od normatívnych politických konotácií. Pozri Siegel, Achim: Introduction: The Changing Fortunes of the Totalitarian Paradigm in Communist Studies. In: The Totalitarian Paradigm after the End of Communism. Towards a Theoretical Reassessment. Ed. A. Siegel. Amsterdam - Atlanta 1998, s. 9-11.

6 Sartori, Giovanni: Teória demokracie. Bratislava 1993, s. 202.

7 Friedrich, Carl J. - Brzezinski, Zbigniew K.: Totalitarian Dictatorship and Autocracy. New York - Washington - London, 1965, s. 22.

8 Linz, Juan J.: Totalitarian and Authoritarian Regimes. London 2000, s. 70.

9 Pozri aj Sartori, G.: Teória, s. 183.

10 Linz, J.: Totalitarian, s. 240-241.

11 Podl’a Friedricha a Brzezinského tvorí centralizované hospodárstva a snaha o kontrolu nezávislých asociácií a skupín, jeden zo znakov totalitného režimu. Pozri Friedrich, J. C. - Brzezinski, K. Z.: Totalitarian, s. 22.

12 Webb, Simone - Webb, Beatrice: The History of Trade Unionism, 1666-1920. Edinburgh 1919, s. 1. 


\section{Talianske odbory pod vplyvom fašistického korporativizmu}

Benito Mussolini stál v roku 1919 pri zrode organizácie Fasci Italiani di Combattimento, ktorá sa sformovala na základe pôsobenia predchádzajúcich fašistických skupín. Už v tejto fáze sa fašisti programovo vymedzili voči odborom, socialistickej strane, formálne aj proti kapitalizmu a cirkvi, avšak ešte bez výraznejšieho politického úspechu. $\mathrm{O}$ dva roky neskôr vznikla fašistická strana. Jej taktika spočívala vo vymedzení sa najmä proti socialistom a hrozbe lavicovej revolúcie, čo strane prinieslo istý úspech v parlamente. Revolučné obdobie po prvej svetovej vojne a príklad bol'ševickej revolúcie v Rusku boli silnými determinantami situácie v Taliansku, kde dlhodobo vládla nestabilná politická situácia. Odbory a socialistická strana v tej dobe organizovali mnohé štrajky, aktívne bolo aj rol’nícke hnutie zamerané proti vel'kostatkárom. Fašisti predstavovali násilný protipól voči takýmto tendenciám. Rozdrvili aj generálny štrajk organizovaný socialistami a konštituovali sa tak ako zábezpeka voči rozvratu talianskeho priemyslu a celkového spoločenského poriadku. ${ }^{13} \mathrm{~V}$ roku 1922 sa Mussolini stal premiérom krajiny, čím sa v Taliansku začala nová politická etapa.

$\mathrm{S}$ fašizmom boli prepojené myšlienky a prax korporativizmu, ktoré následne determinovali aj pôsobenie odborov vo fašistickom Taliansku. Mussolini ako vodca fašistického štátu vyhlásil, že „korporatívny systém je predurčený $k$ tomu, aby sa stal civilizáciou dvadsiateho storočia."14 Korporativizmus mal prekonat kapitalizmus a jeho extrémny liberalizmus, rovnako aj socializmus a jeho etatizmus. ${ }^{15}$ Od nástupu Mussoliniho k moci smerovali tendencie v hospodárskej politike od vol’ného podnikania k štátnym zásahom a kontrole. V talianskom kontexte predstavoval korporativizmus formu rôznych ekonomických metód a inštitúcii, v rámci ktorých sa malo, na pozadí organickej a duchovne stmelenej spoločnosti, dospiet k jednote medzi pracujúcimi a zamestnávatel'mi. Súbežne sa rozvíjala spolupráca medzi štátom a súkromnými podnikmi. ${ }^{16}$

Cesta k vytvoreniu jediných legálnych odborov pod fašistickým monopolom začala v decembri 1923. Spočívala v pakte (Patto di palazzi Chigi) medzi talianskou priemyselnou konfederáciou a fašistickými odbormi ${ }^{17}$ o tom, že uvedú činnost̉ do súladu so zásadami vlády. Pôsobenie organizácií malo sledovat ciel' vzájomnej kooperácie priemyselníkov a pracujúcich. ${ }^{18}$ Fašistické odbory však vo vol'bách do závodných výborov či organizovaní štrajkov nedokázali oslovit pracujúcich tak, ako ešte stále existujúce nefašistické odbory. ${ }^{19}$ Reakciou na tento stav bola d’alšia dohoda (Patto di palazoo Vidoni) z 2. októbra 1925.

13 Lee, J. Stephen: Európske diktatúry 1918-1945. Bratislava 2015, s. 157-158. V roku 1921 zničili ozbrojené skupiny fašistov 119 odborových kancelárií a 83 kancelárií rol’níckych líg. Tamže, s. 165.

14 O’Sullivan, N.: Fašizmus, s. 132-133.

15 Procacci, Guliano: Dějiny Itálie. Praha 2010, s. 346.

16 Lee, J. S.: Európske, s. 190-191.

17 Confederazione generale delle corporazioni fasciste. Vznikli v januári 1922.

18 D'Albergo, Salvatore: Documenti del corporativismo fascista : da Palazzo Vidoni alla Carta del lavoro. Napoli 1995, dokument Patto di palazzi Chigi, http://www.contraddizione.it/docofasc.rtf. Citované dňa 20. 5. 2018. 
Edmondovi Rossinimu sa po predchádzajúcich neúspešných pokusoch podarilo dohodnút so zamestnávatel’skými organizáciami. ${ }^{20}$ Priemyselná konfederácia uznala fašistické odbory za jediného reprezentanta priemyselného robotníctva a fašistické odbory uznali konfederáciu za jediného reprezentanta záujmov priemyselných podnikatelov. Dohodou boli zrušené závodné výbory pracujúcich a ich právomoci prešli na organizácie fašistických závodných výborov. Tie sa ihned' zaviazali, že svoju činnosṫ budú vykonávat len v spojení s príslušnými organizáciami priemyselníkov. Dohoda bola odobrená aj královským dekrétom. ${ }^{21} \mathrm{O}$ pár dní neskôr, 6. októbra, vydala Vel'ká fašistická rada rezolúciu podla ktorej sa mali odbory inkorporovat do štátu, čím by sa dostali plne pod jeho kontrolu. ${ }^{22} \mathrm{~V}$ apríli 1926 fašistický režim rozpustil aj posledné slobodné odborové združenie (Všeobecná konfederácia práce), zrušil právo na štrajk a rozpustil závodné výbory. ${ }^{23}$ Nefašistické odborové organizácie totiž stále predstavovali baštu antifašistických síl a boli početnejšie ako fašistické odbory. Tento stav chcel režim zvrátit. ${ }^{24}$ Opatreniami fašisti dosiahli stav, že „všetok odborový život bol podriadený princípom a ciel’om fašistického štátu. “25

Fašistický korporativizmus našiel svoje ideové vyjadrenie v Charte práce z 21. apríla 1927, prijatej na výročie založenia Ríma. ${ }^{26}$ Chartu práce možno chápat ako nástroj implementácie korporativizmu do talianskej politickej reality. ${ }^{27}$ Určila fašistický štát ako jediný možný rámec realizovania morálnej, politickej a ekonomickej jednoty v podobe talianskeho národa. Manuálna a intelektuálna práca sa chápali ako sociálna povinnost́. Odborové organizácie mohli fungovat iba pod kontrolou štátu. Ministerstvo práce zaviedlo monopolistický režim, ktorý reguloval mzdy a pracovné podmienky. Charta obsahovala aj rôzne detailné ustanovenia týkajúcich sa práv pracujúcich (napr. garantovaný deň odpočinku, zaručenie pracovnej pozície pri chorobe, príplatok za nočnú prácu). Opakovane deklarovala rovnost̉ medzi nimi a zamestnávatel'mi, ktorú mali zaistovat

20 Salvemini, Gaetano: Under the Axe of Fascism. Londýn 1936, s. 31-32. Rossini bol hlavnou postavou fašistického syndikalizmu počas Mussolliniho režimu.

21 Tkadlečková, Helena: Talianska fašistická strana a jej politická ideológia. Bratislava 1969, s. 178-179. Pozri aj Salvemini, G.: Under, s. 32. V apríli toho istého roku prijala Velká fašistická rada uznesenie, v ktorom označila „socialistický štrajk“ uskutočnený mimo systému korporácií ako „akt vojny“ a ako legitímny uznala len „fašistický štrajk.“ Pozri D’Albergo, S.: Documenti, dokument Sul problema dello sciopero, http://www. contraddizione.it/docofasc.rtf. Citované dňa 20. 5. 2018.

22 Pozri D'Albergo, S.: Documenti del corporativismo, dokument Riconoscimento giuridico dei sindacati, http:// www.contraddizione.it/docofasc.rtf. Citované dňa 20. 5. 2018.

23 Štrajk sa vnímal ako urážka štátu a zločin proti „sociálnej vzájomnosti.“ Tresty za štrajkovanie boli finančné a väzobné. Pozri Guérin, D.: Fašismus, s. 179-180. Spomenuté opatrenia boli súčastou legge Rocco (podla ministra spravodlivosti Alfreda Rocca), ktorý predstavoval nový korporativistický rámec pre kolektívne pracovné vztahy. Bližšie pozri Pasetti, Matteo: Neither Bluff nor Revolution. The Corporations and the Consolidation of the Fascist Regime (1925-1926). In: In the Society of Fascists : Acclamation, Acquiescience, and Agency in Mussolini's Italy. Edd. G. Albanese - R. Pergher. New York 2012, s. 89, 94-95.

24 Salvemini, G.: Under, s. 29-30.

25 Pasetti, M.: Neither, s. 95.

26 Tento deň dokonca nahradil oslavy tradičného 1. mája. Pozri Procacci, G.: Dějiny, s. 341.

27 V roku 1927 bolo v Taliansku zriadených 22 korporácií, pričom každá jedna reprezentovala pracujúcich, zamestnávatelov a vládu. Pozri Heywood, Andrew: Political Ideologies. An Introduction. New York 2003, s. 184 . 
práve fašistické odbory. ${ }^{28}$ Ked’ však Ústredný zväz fašistických odborov na svojom zjazde poukázal na fakt, že z „triednej spolupráce“ tažia len zamestnávatelia, bol po tlaku zamestnávatel'ských organizácií v roku 1928 zrušený. Zostali fungovat’ len jednotlivé priemyslové zväzy. ${ }^{29}$ Napriek tomu vtedy Mussollini propagandisticky prehlásil: „Deklarujem, že kapitál a práca majú odteraz rovnaké práva a povinnosti: ako bratia vo fašistickej rodine." 30

Taliansky štát bol spôsobom svojho utvárania a vývoja do značnej miery privatizovaný, čím bol vystavený tlaku najsilnejších a najvplyvnejších ekonomických skupín, ktoré si ho podmanili. Korporácie mali d’aleko k tomu, aby sa stali prostredníkom medzi kapitálom a prácou. Namiesto toho boli závislé na vel'kom priemysle a prostredníctvom neho dokázali najväčšie skupiny a monopoly umlčat všetky požiadavky a protesty pracujúcich. Zástupcovia priemyslu mohli d’alej vykonávat tlak na štát v záujme posilnenia vlastných pozícií. ${ }^{31}$ Takisto sa pričinili o to, aby fašistické odbory zostali pod kontrolou a nezískali vel'ký vplyv. ${ }^{32}$

Možno konštatovat, že Mussoliniho korporativizmus nikdy nebol skutočnou „tretou cestou,“ ale naopak taktikou, pomocou ktorej štát rozšíril svoju kontrolu nad spoločnostou. Tento systém evidentne sledoval záujmy súkromnej sféry. Korporativizmus bol do talianskej spoločnosti zavedený autoritársky. Došlo k násilnej unifikácii organizovaných záujmov do jedného celku medzi zamestnávatel'mi a pracujúcimi, pričom sa štát zasadil o to, aby bola eliminovaná najmä odborová nezávislost'. Taliansky korporativizmus predstavil autokratický a formalizovaný systém reprezentovaných záujmov, ktorý manažoval pracovné vztahy a legitimizoval represiu slobodných odborov tým, že ich kooptoval do kontrolovaného štátneho segmentu. ${ }^{33}$ Treba však dodat, že dobovo predstavoval významnú revolučnú ideu, ktorá získala značnú podporu. ${ }^{34}$

\section{Nacistické Nemecko bez odborov}

Myšlienky korporativizmu sa spočiatku recipovali aj v nacistickom hnutí, ked' nacionálni socialisti hladali inšpiráciu v talianskom fašizme. Podl’a Hitlerovho spisu Mein Kampf mala koncepcia „národno-socialistickej korporatínej myšlienky“ v konečnom dôsledku „na-

28 Carta del Lavoro, https://archive.org/details/FascistLaborCharter. Citované dňa 1. 6. 2018.

Najmä po Velkej hospodárskej kríze sa myšlienky korporativizmu šríili po celej Európe. Práve talianska Charta práce tento proces symbolizovala. Pozri Pasetti, Matteo: The Fascist Labour Charter and its transnational spread. In: Corporatism and Fascism. The Corporatist Wave in Europa. Ed. A. Costa Pinto. New York 2017, s. 70-72.

29 Guérin, D.: Fašismus, s. 189-190.

30 Salvemini, Gaetano: Italian Trade Unions under Fascism. In: The Fate of Trade Unions under Fascism. Edd. J. Francis Gorman - A. Goldschmidt - G. Salvemini. New York 1937, s. 35.

31 Guérin, D.: Fašismus, s. 189-190.

32 Pasetti, M.: Neither, s. 96.

33 Costa Pinto, António: The nature of fascism revisited. New York 2012, s. 123. Pozri aj Guérin, D.: Fašismus, s. 198-202.

34 Pasetti, M.: Neither, s. 87-88. Pozri aj Todini, Giampero: Corporazioni e corporativismo. Per una storia del diritto del lavoro. Sassari 2007, s. 128-129. 
hradit’ ničivý triedny boj. “35 Ako však nacisti postupne nadobúdali politickú silu, vydali sa inou cestou. Hovorili už iba o nacionálnom socializme, čím chceli zdôraznit jedinečnost' ich doktríny. ${ }^{36}$ Jej špecifikom bola rasová teória, ktorej sa mala prispôsobit aj ekonomika. Nacisti snívali o novej spoločnosti, v ktorej mal byt nemecký národ predovšetkým jednotný. V tomto zmysle chceli dosiahnut’ stav, v ktorom dôjde k pohlteniu všetkých spoločenských tried a vytvorí sa tak rasovo čistá organická spoločnost'. ${ }^{37}$

Odborové hnutie prežívalo vo Weimarskej republike niekol'ko rokov pred vel'kou hospodárskou krízou obdobie stability. Ekonomický kolaps však znamenal zásadnú zmenu situácie a oslabenie pozícií zástupcov pracujúcich. Členstvo v odboroch klesalo, čo malo súvis aj s rapídnym nárastom nezamestnanosti. Znižovali sa i príjmy z členského, čím trpeli odborárske aktivity a narastala rezignovanost’ pracujúcich. ${ }^{38}$ Odbory sa však v rámci možností snažili rozdel'ovat dopady krízy medzi prácu a kapitál rovnomerne. ${ }^{39}$ Na povrch sa vynárala aj hrozba vlády nacistov, resp. samotná existencia parlamentnej demokracie, proti čomu vystupovali všetky odbory - napriek nezhodám v iných oblastiach či odlišnej politickej afiliácií. ${ }^{40}$ Vplyv odborov vo Weimarskej republike však nebol natol'ko silný a postup jednotný, aby mohli výrazne ovplyvnit politický vývoj a zamedzit’ nástupu nacistov. ${ }^{41}$

Uchopenie moci Hitlerom a jeho nacistickou stranou prinieslo rýchly zánik odborov v Nemecku. Odboroví predstavitelia dúfali, že sa im podarí zachránit svoje organizácie politikou protestov a stažností, radikálnejšie akcie či generálny štrajk odmietali. Po marcových vol'bách sa však teror vystupňoval 2. mája 1933 nacisti obsadili odborové centrály a zhabali majetok, čím odbory zanikli. ${ }^{42}$ Nacisti v konečnom dôsledku neuznali ani Továrenské bunky nacistickej strany (Nationalsozialistische Betriebszellenorganisation) ako odborovú organizáciu. Tie vznikli v roku 1928 ako nástroj nacistov na získanie vplyvu v závodných radách. Významnú rolu zohrali pri likvidácii odborov, avšak počas „spontánneho teroru,“ ku ktorému prichádzalo od januára 1933, sa táto masová organizácia vymykala z kontroly straníckeho vedenia. ${ }^{43}$ Továrenské bunky najskôr pôsobili paralelne popri NFP, ale ich široké ekonomické (vrátane práva na štrajk) a politické požiadavky (všeobecne zlepšenie situácie pracujúcich) zapríčinili ich potlačenie. Po Noci dlhých nožov a vražde Gregora Strassera sa ich vplyv znížil. V roku 1935 boli včlenené do NFP. ${ }^{44}$

35 O'Sullivan, N.: Fašismus, s. 129-130.

36 Tamže, s. 131.

37 O’Sullivan, N.: Fašismus, s. 130-131. Pozri aj Lee, J. S.: Európske, s. 279, 293.

38 Schneider, Michael: A Brief History of the German Trade Unions. Bonn 1991, s. 180-184.

39 Tamže, s. 185.

40 Tamže, s. 188-189.

41 Tamže, s. 202-203.

42 Tamže, s. 204-206.

43 Mai, Gunther: Die Nationalsozialistische Betriebszellen-Organisation. Zum Verhältnis von Arbeiterschaft und Nationalsozialismus. Vierteljahrshefte für Zeitgeschichte 31, 1983, s. 607.

44 Tamže, s. 609-611. Továrenské bunky, rovnako ako fašistické odbory v Taliansku, nedokázali oslovit pracujúcich. Ešte na konci apríla 1933 sa uskutočnili vol’by do zamestnaneckých rád a Továrenské bunky v nich utrpeli debakel. Aj tento fakt bol významným impulzom pre zrušenie odborov. Pozri Schneider, M.: A Brief, s. 208. 
V sfére práce chceli nacisti udržat pokoj na pracoviskách a zaistit kooperáciu medzi pracujúcimi a zamestnávatelmi. ${ }^{45}$ Práca všeobecne zohrávala v nacionálnom socializme centrálnu úlohu. Podla Hitlerovho rasistického svetonázoru sa rasy zorad’ovali podla ich pracovných kompetencií. „Árijci“ tak napr. nesebecky budovali štát a vykonávali kultúrnu činnost', zatial' čo Židia boli len parazitmi, neschopní vykonávat produktívnu prácu. ${ }^{46}$ Práca sa takisto stala jadrom politickej a zároveň praktickej identity aj pre Nemecký front práce (NFP), ktorý nahradil odborové organizácie. ${ }^{47}$ Vznikol 10. mája 1933 a jeho hlavný predstavitel' Robert Ley od začiatku proklamoval, že jeho cielom nie je byt "frontom pracujúcich," ale "frontom práce." Samotný termín „front" mal implikovat militarizáciu práce, teda jej úplné podriadenie vojnovej ekonomike. ${ }^{48}$ Rovnako sa militarizovali aj sociálne vztahy, ktoré nacistický ideologický naratív zredukoval na boj o prežitie a nadvládu, čo viedlo $\mathrm{k}$ zmene celkovej rétoriky. Pomer medzi zamestnávatelmi a pracujúcimi sa tak vnímal ako vztah „lídrov a nasledovnikov," snaha o ukončenie nezamestnanosti sa stala „bitkou o prácu,“ zamestnanie sa premenilo na „pracovné nasadenie“ a pracovno-odborné poradenstvo na "pracovno-odborné riadenie. " 49

Nemecký front práce združoval okolo 25 miliónov nemeckých pracujúcich všetkých povolaní a postavení. Za hlavný ciel si kládol skoncovat s triednym bojom a vytvorit jedinú organizáciu, ktorá by riešila všetky oblasti pracujúcich - od platových otázok, cez pracovné podmienky až po ich volný čas.$^{50}$ Pokial ide o postavenie NFP a jeho vztahu k strane, Ley sa vyjadril nasledovne: „... Strana bola jediným zdrojom moci v novom Nemecku. Pre tento dôvod som Nemecký front práce umiestnil priamo pod stranicke vedenie... Nemecký front práce sa tak nevyvinul v korporatívnu organizáciu. "51 NFP bol formálne naozaj viac zodpovedný strane ako vláde, v skutočnosti však nikomu, ked’že Ley ako líder NFP a zároveň „Reichsorganisationsleiter" ${ }^{\text {"52 }}$ trval na svojom priamom prístupe $\mathrm{k}$ Hitlerovi z titulu oboch svojich funkcií. ${ }^{53}$ Špecifikom bolo už spomínané zameranie sa na volný čas pracujúcich. $\mathrm{V}$ rámci NFP fungovalo rekreačné oddelenie Radostou k sile, ktoré malo viacero cielov vrátane zaháňania nudy. Ley to vysvetlil nasledovne: „Z nudy pramenia hlúpe, kacírske, a áno, nakoniec i zločinné myšlienky a myšlienkové pochody... pre štát neexistuje vä̌čsie nebezpe-

45 Carsten, Francis Ludwig: The German Workers and the Nazis. Aldershot 1995, s. 15.

46 Buggeln, Marc - Wildt, Michael: Arbeit im Nationalsozialismus (Einleitung). In: Arbeit im Nationalsozialismus. Edd. M. Buggeln - M. Wildt. München 2014, s. XXXV.

47 Deutsche Arbeitsfront.

48 Hachtmann, Rüdiger: Arbeit und Arbeitsfront: Ideologie und Praxis. In: Arbeit im Nationalsozialismus. Edd. M. Buggeln - M. Wildt. München 2014, s. 87.

49 Meskill, David: Optimizing the German Workforce : Labor Administration from Bismarck to the Economic Miracle. New York - Oxford 2010, s. 145.

50 Overy, Richard: Tretia ríša. Kronika. Bratislava 2011, s. 83. Nemecký front práce však nemal záujem intervenovat do sféry miezd. Jeden z ich predstavitelov sa vyjadril, že nacisti zavrhujú tzv. „marxistickú mzdovú politiku." Regulácia miezd tak zostala plne v rukách zamestnávatel’ov, resp. štátu. Pozri Carsten, F. L.: The German, s. 33.

51 Schoenbaum, David: Hitler's Social Revolution. Class nad Status in Nazi Germany, 1933-1939. Toronto 1980, s. 83.

52 Seniorská pozícia ríšskeho inšpektora.

53 Mason, Tim: Some Origins of the World War Two. Past and Present 29, s. 84. 
čie." Z tohto dôvodu malo oddelenie za úlohu organizovat' rôzne kolektívne rekreačné aktivity, ktoré však boli úplne kontrolované. ${ }^{54} \mathrm{~V}$ duchu všadeprítomnej kontroly vznikol 19. mája 1933 systém pracovných dôverníkov, ktorí dozerali na určovanie miezd. Samotní pracujúci však medzi nich nepatrili. Továrenské výbory, ktoré slúžili ako priestor pre diskusiu na rôzne témy medzi pracujúcimi a predstavitel'mi NFP, boli obsadené členmi straníckych buniek vo fabrikách. Funkcia NFP teda spočívala v eliminácii každej potenciálnej hrozby zo strany pracujúcich. ${ }^{55}$

K ideológii nacionálneho socializmu patrila štylizácia Hitlera ako pracujúceho, pričom sa odkazovalo na dobu, ked' sa živil manuálnou prácou. ${ }^{56} \mathrm{~V}$ akomsi ideologickom katechizme nacizmu bolo možné nájsț otázku: „Aké profesie zastával Adolf Hitler?“ Odpoved' bola: „Adolf Hitler bol pracovnik na stavbe, umelec a študent. "57 Tretia ríša priniesla ideológiu práce, ktorá apelovala na hrdost’, patriotizmus, idealizmus a pracovný étos. Nezameriavala sa tak na pracujúcich, ale na prácu samotnú. ${ }^{58}$ Oficiálna propaganda hlásala, že heslo Sloboda - Rovnost’ - Bratstvo, ktorým „oklamali a zradili nemeckého pracujúceho liberálno-marxisticki demagógovia, "sa stalo realitou až vd’aka nacionálnemu socializmu. ${ }^{59}$ Takisto možno uviest, že aj napriek prehnanému zdôrazňovaniu tohto motívu marxisticky orientovanými historikmi, nemožno ignorovat’ jeden aspekt fungovania nacistického režimu. Predstavitelia režimu a priemyselného kapitálu dospeli k zhodnej predstave o fungovaní spoločnosti, podobne ako vo fašistickom Taliansku. Podnikatel'ským vrstvám režim poskytol nebúriacu sa a výkonnú pracovnú silu bez pôsobenia problematických odborových združení.$^{60}$ Kvôli štrajkovaniu a protestom mohli pracujúci skončit v koncentračnom tábore. Až 100000 lavicovo orientovaných robotníkov sa preto v roku nástupu nacistov k moci dostalo automaticky do koncentračných táborov. Nacisti zariadili prepustenie z práce tisícom socialistom a komunistom. ${ }^{61}$ Napriek týmto krokom však existuje celý rad dôkazov o tom, že robotníci sa nikdy nestali integrovanou súčastou nacistického Volksgemeinschaft. ${ }^{62}$ Ich odcudzenie bolo vyjadrené mnohými aktmi odporu v oblasti pracovnej disciplíny a subordinácie. Konkrétne išlo napr. o absentizmus, sabotáže, menšie štrajky, tlak na lepšie mzdy a pracovné podmienky. ${ }^{63}$ Treba však dodat aj to, že odpor pracujúcej triedy v Nemecku nedosiahol revolučnú úroveň doby po prvej svetovej vojne. Jedným

54 Burleigh, Michael: Třetí říše. Nové dějiny. Praha 2008, s. 210-211. Radostou k sile organizovala koncerty, návštevy exhibícii, divadiel, opier, exkurzie do miest či prírody. Pozri viac Carsten, F. L.: The German, s. 35-36. Existovala aj organizácia Krása práce (Schönheit der Arbeit), ktorej cielom bolo skultúrňovanie a skrášlovanie pracovného prostredia. Pozri Lee, J. S.: Európske, s. 286.

Overy, R.: Tretia, s. 83.

Burleigh, M.: Třeti, s. 203-205.

Viac ku glorifikácii „pracujúceho“ a štylizovania sa Hitlera do tejto pozície, pozri Schoenbaum, D.: Hitler's, s. $57-58$.

Tamže, s. 75.

Tamže, s. 77.

Lee, J. S.: Európske, s. 272.

Burleigh, M.: Třetí, s. 204-205.

Ideál harmonického a pokrvne spojeného l’udového spoločenstva, ktoré zdiel'a spoločné politické postoje a osud.

63 Mason, Tim: Nazism, Fascism and Working Class. Cambridge 1996, s. 23. 
z vysvetl'ujúcich faktorov je práve likvidácia odborov (absencia platformy pre ilegálnu činnost') a masívna represia. ${ }^{64}$

\section{Odbory v Slovenskom štáte: fáza fašisticko-korporativistickej transformácie}

Po Mníchovskej dohode došlo na Slovensku k radikálnej zmene politických pomerov. Hlinkovej slovenskej ludovej strane (HSL'S) sa podarilo uchopit moc a došlo k vyhláseniu slovenskej autonómie v rámci Česko-Slovenska. Dominantné postavenie HSLS malo za následok koniec politickej plurality. Nastalo zjednodušovanie pomerov. Proces tzv. „zglajchšaltovania“ postihol aj odborové hnutie a krestanské l’udácke odbory. Tie, dovtedy pôsobiace v pluralitnom prostredí, sa stali jedinými legálnymi odbormi na Slovensku. Jozef Tiso už krátko po vyhlásení autonómie vo verejnom prejave vyhlásil: „Vodcom robotnictva nesmie byt' odteraz Marx, ani Lenin! Jeho vodcom musi byt' Kristus, lebo len od Jeho náuky môže očakávat’ spravodlivé riešenia problémov. " 65 Ostatné odborové organizácie l'udáci zrušili (ako prvé komunistické Červené odbory) ${ }^{66}$ „Zglajchšaltovanie“ prebehlo pomerne rýchlo, ešte počas roka 1938. Následne sa až 28. februára 1939 de iure potvrdil status quo, ked' došlo k rozhodnutiu zhabat majetok zrušených odborových organizácií. ${ }^{67} \mathrm{~V}$ nových politických pomeroch boli niektoré úlohy sociálneho charakteru zverené do agendy činitelov krestanských odborov, ${ }^{68}$ ktoré sa tak priamo podielali na budovaní nového režimu. Likvidácia bývalých odborových skupín a zaistovanie ich majetku prebiehali aj krátko po vzniku Slovenského štátu. Vo veci konali okresné súdy, ktoré v jednotlivých prípadoch vychádzali z vládneho nariadenia zo 16 . marca 1939 č. 10 Sl. z. a výnosu ministerstva vnútra z 20. marca č. 5887/1939. ${ }^{69}$

Vyhlásenie Slovenského štátu 14. marca 1939 neprinieslo žiadny okamžitý zlom. Pokračovalo sa v trende nastolenom v druhej republike. Pre neskorší vývin bolo dôležité, že Slovenský štát vznikol ako vedlajší produkt nacistickej zahraničnej politiky a mal do značnej miery status satelitu Tretej ríše. Čo sa týka zániku Česko-Slovenska činitelia krestanských odborov nemali proaktívny prístup. Situáciu chápali ako nevyhnutnú vzhladom

64 Kershaw, Ian: Popular Opinion and Political Dissent in the Third Reich. Bavaria 1939-1945. Oxford 2002, s. 313-314.

65 Tiso, Jozef: Prejavy a články (1938-1944). Edd. M. Fabricius- K. Hradská. Bratislava 2007, s. 16.

66 Chreňová, Júlia: Dokumenty k dejinám komunistickej strany na Slovensku (1938-1944) I. Bratislava 1988, s. 52-57. Zákaz odborov priniesol aj praktické problémy pre v nich organizovaných pracujúcich. Policajné orgány zhabaním spisov odborovej organizácie znemožnili vyplácanie podpôr v nezamestnanosti. Pozri Slovenský národný archív (d’alej len „SNA“), Ministerstvo vnútra 1938-1945, kartón (d’alej len „kart.“) 24, inventárne číslo (d’alej len „inv. č.“) 8969/1939.

67 Štátny archív v Trenčíne, pobočka Považská Bystrica, Okresný úrad Považská Bystrica, kartón 81.

68 Katuninec, Milan: Charakter rakúskych a slovenských krestanských odborov v prvej polovici 20. storočia. Historický časopis 55, 2007, s. 716. 18. decembra 1938 sa uskutočnili vol'by do slovenského snemu. Poslancami sa stali aj funkcionári krestanských odborov, a to Rudolf Čavojský ako hlavný tajomník, predseda združenia František Slameň a ústredný tajomník Jano Mora. 
na medzinárodný kontext. ${ }^{70}$

Krestanské odbory ideologicky vychádzali priamo z pápežských sociálnych encyklík. ${ }^{71}$ Viackrát sa na ne odvolávali a považovali ich myšlienky za určujúce. V lete 1939 sa v kontexte prípravy novej ústavy debatovalo o všeobecnom smerovaní Slovenského štátu. Ústava nového štátu bola prijatá 21. júla 1939. Obsahovala návrh korporativistického zriadenia, ${ }^{72}$ zákaz štrajku či motív pol'udštenia kapitalizmu, ktorý sa objavoval už v sociálnych pápežských encyklikách a l’udácki politici, vrátane krestanských odborárov, ho preberali a šírili d’alej. Rozpracovaný bol dvorným ideológom režimu Štefanom Polakovičom. ${ }^{73}$ Debata o charaktere nového režimu pokračovala d’alej a v ideovom smere sa zredukovala na to $\mathrm{v}$ akej podobe a či vôbec prijat’ stavovské zriadenie, ktoré malo primárne zabezpečit sociálny zmier.

Podpredseda slovenského snemu Karol Mederly hovoril o tretej ceste medzi kapitalizmom a socializmom. ${ }^{74}$ Dochádzalo ku kritike liberálnej hospodárskej politiky, v ktorej videli príčinu nezamestnanosti, opakujúcich sa ekonomických kríz a sociálnej nestability. Korporativizmus mal nahradit liberalizmus v oblasti pracovného trhu. Stará paradigma mala ustúpit novej - tá spočívala v zmesi kontroly, donucovania a integrácie pracujúcej triedy do národného spoločenstva. ${ }^{75}$ Vzorom bolo najmä fašistické Taliansko, pričom slovenskí politici boli s jeho predstavitel'mi v kontakte. Taliansky konzul v Bratislave Lo Faro si poznamenal, že sa zaujímali najmä o fašistické idey a inštitucionálnu prax. ${ }^{76}$

Debaty o pripravenom návrhu stavovského zriadenia boli náročné. Odborári boli k stavovskému systému predostretému v ústave kritickí. ${ }^{77}$ Ak by sa však korporativizmus uviedol do praxe, odborári navrhovali, aby sa odbory stali podkladom pre organizovanie

70 Viac pozri Pleva, Ján - Tichý, Miloš: Krestanské odbory. Bratislava 1967, s. 100-101.

71 Najmä Rerum Novarum a Quadragesimo anno.

72 Pozri Ústava Slovenskej republiky, hlava siedma § 60. In: Ed. M. Pekár. Komentované pramene k dejinám Slovenska 1939-1945. Košice 2015, s. 29-30. Návrh radí obyvatelov do šiestich stavov: polnohospodárstva, priemyslu, obchodu a živností, peňažníctva a poistovníctva, slobodných povolaní, verejných zamestnancov a osvetových pracovníkov. Každý z konkrétnych stavov bol tvorený zamestnávatelmi a pracujúcimi, ktorí sa mali starat o zvýšenie výkonnosti a životnej úrovne v hospodárskej, sociálnej či kultúrnej rovine. Stavy mali mat̉ v agende aj riešenie pracovných pomerov. $\mathrm{V}$ neposlednom rade, podobne ako v Taliansku, mali stavy slúžit ako platforma na riešenie konfliktov medzi zamestnancami a pracujúcimi.

73 Napríklad: „Ciel'om... je spravodlivé rozdelenie hmotných statkov. I ked’ všeobecná rovnost’ je nezmyslom (s rozdielmi sa už rodime) - dôsledne uskutočňovaná sociálna politika nášho štátu smeruje $k$ tomu, aby sa v našom národe vyrovnali rozdiely medzi jednotlivými triedami. V slovenskom štáte nechceme hospodársky a sociálny systém, ktorý by vychovával žobrákov - proletárov, ktorý by bol pareniskom zbohatlikov bez práce... Nové Slovensko je protikapitalistické, sociálne... Toto nové sociálne, nie socialistické Slovensko bude hojit' rany, ktoré ešte sú, bude odstraňovat' biedu, ale nebude vychovávat' darebákov zo všelijakých fondov a podpôr nezamestnanosti... Nové Slovensko nie je proti kapitálu, ale je proti nesvedomitým kapitalistom... Kapitál môže na Slovensku pracovat', slušne zarábat’, ale je povinný slúžit predovšetkým Slovensku a záujmom slovenského národa. "Pozri Polakovič, Štefan: Tisova náuka. Bratislava 1941, s. 321-324.

74 Slovák, 25. 7. 1939.

75 Vilar-Rodríguez, M.: The labour, s. 3.

76 Klabjan, Borut: Taliansko a Slovensko vo vojne. Vplyv talianskeho fašizmu na Slovensko pred druhou svetovou vojnou a počas nej. Historický časopis 54, 2006, s. 458.

77 Čavojský, Rudolf: Spomienky krestanského odbojára. Bratislava 1996, s. 5, s. 46. Pozri aj Slovenský robotnik, 1. 2. 1940 . 
stavov, pričom členstvo v nich malo byt povinné. ${ }^{78}$ Týmto návrhom sledovali posilnenie vlastnej pozície. Zasadnutie slovenského snemu 13. marca 1940 prinieslo záver, že zákon o stavoch kvôli jeho komplexnosti nemôže byt’ v krátkej dobe prijatý. Možno konštatovat', že stavovské zriadenie nakoniec nebolo zrealizované pre viaceré dôvody. Jedným z nich bol aj postoj Nemecka k tejto otázke. ${ }^{79}$

Odbory sa okrem diskusie o implementácii korporativizmu venovali aj klasickým odborárskym témam - angažovali sa v pomerne mnohých mzdových akciách. ${ }^{80}$ Dokonca sa za roky 1939-1940 uskutočnilo najviac mzdových akcií vôbec. ${ }^{81}$ Avšak, vzhl’adom na vlastné ideologické pozadie, mala podpora pracujúcich svoje hranice. Najmä v roku 1940, ked' nespokojnost’ so sociálnou situáciou viedla k viacerým štrajkom a demonštráciám, krestanské odbory tlmili radikálnejšie aktivity pracujúcich. Na niektorých miestach sa však aj funkcionári odborov nechali strhnút a zúčastnili sa štrajkov. ${ }^{82}$ Ked’ sa krestanské odbory dostali pri vyjednávaní so zamestnávatel'mi do patovej situácie , napr. pokial' išlo o výšku miezd, požiadali ministerstvo vnútra o vyriešenie situácie. Samotné ministerstvo tak slúžilo ako arbiter a určilo záväzné mzdy. Odbory neeskalovali situáciu a nepokračovali v spore, naopak vzdali sa zodpovednosti. ${ }^{83}$

Krestanské odbory sa angažovali aj v iných sférach, ktoré pomáhali zlepšit sociálnu situáciu pracujúcich. ${ }^{84}$ Práve pre tieto aktivity sa Rudolf Čavojský ako hlavný predstavitel' krestanských odborov, rovnako ako aj celé odbory, dostávali do nemilosti radikálneho krídla HSLS. Na stránkach denníka Gardista, ktorý bol ich hlásnou trúbou, začali proti nim viest' kampaň. Čavojského označovali za „bol’ševického agenta,“ za podvratný

78 Prejav Rudolfa Čavojského v Slovenskom sneme, 21. júl 1939, http://www.nrsr.sk/dl/Browser/Document?documentId=135154. Citované dňa 1. 6. 2018.

79 Halon, Ludovít - Schvarc, Michal: Predstavy, realita a medzinárodný kontext sociálneho štátu v Slovenskej republike 1939-1945. Historický časopis 62, 2014, s. 658

80 Akcie mali aj pozitívny dopad, čo sa týka úlohy krestanských odborov, tak najmä v oblasti drahotných výpomocí. Pozri Pleva, J. - Tichý, M.: Krestanské, s. 137. Autori dodávajú: „'Správa o činnosti odborovej organizácie slovenských robotnikov,' ktorá sa mala predložit’ zjazdu, vykázala pozoruhodné údaje. Svedčila o tom, že v tomto smere sa dosiahli určité čiastkové úspechy. Práca odborov nebola teda úplne zbytočná. Bolo by iste nesprávne, tieto výsledky nedocenit'. Drobné ústupky zo strany zamestnávatel'ov nemohli, pravda, viest' k podstatnej zmene v postavení robotnikov."

81 Ďalej možno uviest’ napr. žiadost’ odborov o zvýšenie miezd v oblasti stavebného podnikania, pozri SNA, Ministerstvo vnútra 1938-1945, kart. 701; či rezolúciu odborov, v ktorej žiadali, aby slovenská vláda zasiahla do mzdového sporu, ktorý sa týkal pracujúcich vo viacerých podnikoch. Požadovali v nej ustálenie miezd pre jednotlivé odvetvia priemyslu na Slovensku a takisto drahotné príplatky kvôli vzrastajúcej drahote tovarov a potravín, pozri SNA, Ministerstvo vnútra 1938-1945, kart. 1203, inv. č. 19782/1940.

82 Pleva, J. - Tichý, M.: Krestáanské, s. 140.

83 Pozri príklad mzdového sporu vo firmách z oblasti papiernického priemyslu, SNA, Ministerstvo vnútra 1938-1945, kart. 24, inv. č. 137245/1940. Pozri aj SNA, Ministerstvo vnútra 1938-1945, kart. 24, inv. č. 140276/1940 - vo veci dohody o vyplatenie drahotnej výpomoci v roku 1940 firmami pôsobiacimi v pozemnej regulácii vôd a kameňolomoch.

84 Napríklad 10. apríla 1940 prijala vláda návrh krestanských odborárov, na základe ktorého boli do pracovného pomeru prednostne prijímaní nemajetní robotníci s viacčlennými rodinami a osoby, ktoré boli na prácu najviac odkázané. Pozri Katuninec, Milan: Krestanské robotnicke a odborové hnutie na Slovensku. Trnava 2006, s. 166. Pozri aj Pleva, J. - Tichý, M.: Krest’anské, s. 137. 
a protinemecký živel. ${ }^{85}$ Odborári sa vyjadrovali aj proti drahote, artikulovali nespokojnost’ s riešením sociálnych problémov štátu na pôde snemu či intervenovali v rámci kolektívnych zmlúv. Slovenská vláda však presadila, aj pod tlakom loby zamestnávatelov, nevypovedatelnost̉ existujúcich kolektívnych zmlúv, čo staž̌ilo vyjednávanie odborov v prospech vyšších miezd. Avšak napr. v oblasti stavebníctva participovali na tomto opatrení v zhode s vládou a zamestnávatel'skými organizáciami aj krestanské odbory. Spoločne argumentovali v prospech autoritatívneho určovania miezd, pričom tvrdili, že „len vládou určené mzdy budú v stave zaistit pokoj v pracovných pomeroch." $86 \mathrm{~V}$ roku 1939 tak odbory dokázali vyjednávat takmer výlučne len drahotné výpomoci. Kontrolované boli ich organizačné záležitosti. Ked' nejaká odborová skupina organizovala valné zhromaždenie, musela o akcii informovat Policajné riaditel'stvo, predstavit program udalosti a čakat na schválenie akcie. Na zhromaždení sa smeli riešit iba spolkové záležitosti bez politického presahu ${ }^{87}$

\section{Nástup slovenského národného socializmu a zánik odborov}

Zlomovým momentom boli Salzburgské rokovania v júli 1940, po ktorých sa k moci dostali pronacistickí radikáli z HSLS. Skončila éra dominantných talianskych fašistických vzorov a začala éra slovenského národného socializmu silne ovplyvnená nacistickou praxou. Čavojský ju označil za obdobie „plné trpkosti“. So Salzburgom prišiel začiatok konca krestanských odborov na Slovensku. Na odborový tlačový orgán sa uvalila cenzúra. Cenzurované boli aj rozhlasové prejavy Čavojského a to novým ministrom vnútra Alexanderom Machom. ${ }^{88}$ Zaujímavým fenoménom bolo, že za krestanské odbory sa postavili ilegálne pôsobiaci komunisti. Tí k nim boli inak vel'mi kritickí, avšak ich platformu využívali v zmysle pôsobenia na pracujúcich a iniciovanie rôznych aktivít. V augustových smerniciach pre činnost’ okresných a miestnych funkcionárov ilegálnej komunistickej strany uviedli, že akcie robotníkov a rolníkov majú prebiehat „v závodoch, vo fabrikách, na stavbách atd., všade za zvýšenie miezd, za drahotný prídavok a za lepšie kolektínne zmluvy, za robotnicke odbory - proti splynutiu s HSL'S." 89 Podobne aj v Taliansku začala od istého času slúžit platforma existujúcich odborov na ilegálne aktivity.

85 Tamže, s. 150.

86 SNA, Ministerstvo vnútra 1938-1945, kart. 1216, inv. č. 36095/1940.

87 SNA, Policajné riaditel'stvo, kart. 168, kart. 677, kart. 678, kart. 680, kart. 682.

88 Čavojský, R.: Spomienky, s. 52. Pokračovali aj útoky v Gardistovi: „Robotníci sú zmýšlania národnosocialistického... Ak niekto nemá právo hovorit’ v ich mene, tak je to Čavojský... Tieto demokratické spôsoby už vlani v auguste boli zastavené. Teraz sa však znova ozývajú. Upozorňujeme na to zodpovedných vedúcich štátu! Pozri Gardista, 22. marec 1941.

89 Chreňová, J.: Dokumenty, s. 415-416. Podrobnejšie k využívaniu platformy odborov na ilegálnu činnost’ a podnecovanie štrajkových aktivít som sa venoval v samostatnej štúdii. Šumichrast, Adam: Štrajkové hnutie v Považskej Bystrici (1939-1940). In: České, slovenské a československé dějiny 20. století XII. Edd. J. Karpíšek - Z. Sturz - M. Bláhová. Hradec Králové 2017, s. 105-116. 
Problematickou rovinou fungovania krestanských odborov bolo ich začlenenie do HSLS. ${ }^{90}$ Treba však dodat, že tento krok nevnímali krestanskí odborári spočiatku vyslovene negatívne. Naopak, snažili sa v ňom o akúsi garanciu zachovania svojho združenia. Čavojský situáciu komentuje v tom zmysle, že to pre odbory nie je nová situácia, pretože strana reprezentuje slovenský národ a odbory takisto slúžia národu. Zaoberal sa skôr praktickým hladiskom, akoby toto včlenenie malo prebiehat' a v konečnom dôsledku vyzerat. ${ }^{91}$ Ďalším zlomom bol vládny zákon, ktorý po vzore talianskej charty práce zaviedol monopolistický režim umožňujúci reguláciu miezd a pracovných podmienok. ${ }^{92}$ Zákon sledoval zamedzenie konfliktov medzi pracujúcimi a zamestnávatel'mi. ${ }^{93}$

Odbory sa tak v podstate stali zbytočnými, ked’že už nemali ako vstupovat do otázky výšky miezd pracujúcich. Koncom októbra bol zavŕšený proces včlenenia odborov do strany. Podla Tisových slov: „Odborové organizácie včleňujeme do strany. Nie je to jednoduchá vec... Týmto prispôsobujeme sa dnešným potrebám a takto zjednodušujeme politický život. Týmto tvoríme a budujeme jedinú a jednotnú národnú pospolitost. " "94 Odbory teda ešte neboli úplne zlikvidované, ale ich existencia bola sformalizovaná. Vojtech Tuka sformuloval ako prominent slovenského národného socializmu na začiatku roka 1941 štrnásṫ bodový program. Predstavil v ňom myšlienku, že práca je najvyššou hodnotou, čo bolo evidentne prebraté od nacistov. Ďalej napísal: „Kým demokratické a liberalistické režimy rozbili národ na dve polovice - na zamestnávatelov a zamestnancov - národný socializmus spája ich v jednotný front, a keby sa vol’akomu nechcelo pracovat', na to sú národnosocialistické pracovné tábory. " 95 Tuka tak načrtol d’alší vývoj na poli práce.

Proces zániku krestanských odborov došiel do d’alšej fázy, ked' na základe rozhodnutia užšieho predsedníctva HSL'S zo 4. septembra 1941 prestali z právneho hladiska existovat'. Posledné zasadnutie ústredného predstavenstva sa konalo koncom októbra $1941 .{ }^{96}$ Každopádne, ešte v máji 1942 sa ich ústredie zasadilo o prijatie svojho spriazneného človeka ako člena robotníckeho výboru v zbrojovke v Považskej Bystrici. ${ }^{97}$ Konali sa dokonca aj

90 Širšie predsedníctvo HSL'S sa 29. augusta 1940 uznieslo, že všetky zamestnávatel'ské a zamestnanecké organizácie majú byt’ včlenené do strany. Pozri Slovenský robotnik, 1. september, 1940.

91 Tamže.

92 Vládny návrh zákona o určovani miezd (platov) a pracovných podmienok z októbra 1940, http://www.nrsr.sk/ dl/Browser/Document?documentId=294. Citované dňa 25. 5. 2018. Pozri aj Pasetti, M.: The Fascist, s. 70.

93 Prorocky sa v tomto ohlade vyjadril dvorný ideológ režimu Štefan Polakovič už v roku 1939: „... vládny systém musi tu zasahovat' ako regulátor hospodárskeho podnikania práve tak, ako je to Taliansku, Nemecku, Portugalsku, Španielsku a iných autoritatínych štátoch. Regulované hospodárstvo, vedené štátnou autoritou, je jediným prostriedkom ako preklenút' rozdiely a konflikty medzi kapitálom (teda súkromným majetkom) a robotnictvom." Pozri Polakovič, Štefan: K základom slovenského štátu - Filozofické eseje. Turčiansky sv. Martin 1939, s. 162.

94 Tiso, J.: Prejavy a články, s. 291. V tejto súvislosti sa hovorilo o „výchovnom poslani odborových organizácii.“ Pozri Slovenský robotnik, 21. november 1940.

95 Pekár, M.: Komentované, s. 61.

96 Katuninec, M.: Krestáanské, s. 191. V tom čase nadobudol platnost̉ zákon o záujmových združeniach. Rok 1941 sa udáva ako rok zániku odborov aj v iných prácach, napr. Slovenské krestanské odbory včera a dnes. Ed. R. Čavojský, Rudolf ml. Bratislava 2001, s. 65.

97 Štátny archív v Bytči, Zbrojovka Považská Bystrica 1896-1955, kart. 151. 
valné zhromaždenia regionálnych skupín. ${ }^{98}$ Definitívny zánik súvisí až so vznikom novej organizácie združujúcej pracujúcich. Návrh poslanca Čavojského na zriadenie Slovenskej pracujúcej pospolitosti (SPP) sa prvýkrát riešil na zasadnutiach viacerých snemových výborov 29. apríla 1942. ${ }^{99}$ Zákon č. 70/1942 Sl. z. o SPP bol prijatý 6. mája. ${ }^{100}$ Ministerstvo vnútra následne 1. augusta 1942 vydalo vyhlášku č. 368/1942, ktorou sa bývalé odbory zlúčili so Združením priemyslu, živností a peňažníctva. ${ }^{101}$

Čavojský sa na stránkach odborárskeho časopisu vyjadril, že krestanské odbory „prestali v skutočnosti jestvovat’ a účinkovat’ v druhej polovici roka 1942. "102 Do tlačového orgánu odborov napísal 19. novembra 1942 článok s nadpisom „Lúčime sa, ale zostávame spolu." V ňom bližšie objasňuje definitívny zánik odborov a ich jednotlivých miestnych skupín a platobní v SPP. ${ }^{103}$ Prebehla tak úplná zmena, ked' odbory zanikli a po nacistickom vzore NFP vznikla nová organizácia. Likvidácia jednotlivých odborových organizácií od okresnej úrovne prebiehala v rokoch 1942 a $1943 .{ }^{104}$

Slovenskú pracujúcu pospolitost’ tvorili štyri záujmové združenia. Jedným z nich bolo Združenie príslušníkov priemyslu, živností a peňažníctva, do ktorého spadali robotníci spolu so zamestnávatel'mi v daných oblastiach. ${ }^{105}$ Jednoznačným cielom bolo dosiahnut sociálny zmier. Najmä v tomto duchu SPP ideologicky pôsobila a vyvíjala aj praktickú činnost'. SPP nemala v žiadnom prípade odborársky charakter. Ciel’om združenia malo byt' „nájst' spôsob, ako vyrovnat' záujmy medzi zamestnávatel’om a zamestnancom, medzi podnikmi a l’ud’mi, ktorí sú na podnik odkázani... zabezpečenie spolupráce jednotlivých svojich zložiek... docielit' vaájomnú dôveru medzi zamestnávatelmi a zamestnancami, u podnikov porozumenie pre oprávnené požiadavky zamestnanectva a u zamestnancov pre záujmy podnikov. Združenie bude spolupracovat' pri upravovani pracovných a mzdových podmienok, v záujme pospolitosti vplývat' na výrobu a odbyt, usilovat' sa o zdravé sociálne reformy... nejde tu o triedenie a štiepenie síl, ale o vybudovanie pevných hospodárskych a sociálnych celkov, ktoré správnou výchovou svojho členstva a zmeranim výkonnosti a odolnosti $i$ v tých najtažšich časoch budú vediet’ pôsobit’ ako centrálne konsolidačné telesá. "106 Zo stránok Slovenského robotníka vyčítame, že predstavitelia združenia na viacerých úrovniach a pri rôznych príležitostiach pôsobili vo vyššie uvedenom zmysle. Informovalo sa aj o „vzornom“ a „disciplinovanom“ robotníctve v rôznych

98 Pozri SNA, Policajné riaditel'stvo, kart. 170, kart. 562.

99 SNA, Ministerstvo vnútra 1938-1945, kart. 703, inv. č. 1604/g-S405.

100 Jeho prijatím sa automaticky zrušil dovtedy platný zákon č. 297/1940 o slovenských záujmových organizáciách. Pozri zákon č. 70/1942, Slovenský zákonník čiastka 22, vydaný dňa 23. mája 1942, s. 508-510.

101 SNA, Policajné riaditel'stvo kart. 168, kart. 712.

102 Čavojský, R.: Spomienky, s. 70.

103 Slovenský robotnik, 19. novembra 1942.

104 SNA, Policajné riaditel'stvo, kart. 170, inv. č. 26/77.

105 Na čele združenia stál Ján Mikula. Svoje pôsobenie a činnost’ organizácie opisuje vo svojich spomienkach, pričom ich vykresluje značne nekriticky a idealisticky. Pozri Mikula, Ján: Cesta života tŕnistá. Bratislava 1992, s. 30-35. Medzi d’alšie združenia patrili: Pôdohospodárske združenie, Združenie príslušníkov slobodných povolaní a Združenie štátnych a verejných zamestnancov.

106 Slovenský robotnik, 13. augusta 1942. 
podnikoch. ${ }^{107}$ Takisto vznikla aktivita s názvom Radostou k práci, čo bola evidentná inšpirácia nacistickou praxou. ${ }^{108} \mathrm{~V}$ rámci SPP už platilo, na rozdiel od krestanských odborov, povinné členstvo aj s platbou členského. Členov do jednotlivých združení nahlasovali zamestnávatelia. Zmena spočívala aj vo vol'be funkcionárov v jednotlivých organizáciách. Presadila sa vol'ba zhora nadol, čím išlo o vertikálny spôsob riadenia organizácie. Tiso menoval predsedov pre jednotlivé združenia na návrh predsedu SPP, ktorý rozhodoval napr. o predstavenstve a výbore organizácie. ${ }^{109}$

Poslednou zlomovou epizódou slovenských odborov v Slovenskom štáte bolo dianie počas Slovenského národného povstania. Vtedy sa na povstaleckom území položili základy pre pôsobenie odborov v obnovenom povojnovom Československu. ${ }^{110}$

\section{Transformácia či zánik?}

Vývoj pôsobenia odborov v diktátorských režimoch prebiehal rôzne, avšak popri odlišnostiach možno nájst̉ aj viaceré zhodné body. Ak začnem tažiskom textu, po analýze fungovania krestanských odborov v l'udáckom Slovenskom štáte možno konštatovat, že panoval istý rozpor v ich myslení a konaní. Na jednu stranu si uvedomovali, že najmä sociálna sféra zostáva na pokraji záujmu slovenskej vlády. Preto aj vyvíjali snahy, ktoré mali napravit’ tento stav. Na druhú stranu však kresţanské odbory nedokázali prekročit vlastný tieň. Daný stav zapríčinili ich ideologické pozadie a pozície, z ktorých vychádzali. Dôležitým aspektom bola aj lojalita k režimu a vláde. Odboroví činitelia kritizovali isté oblasti, bojovali za čiastkové zlepšenia v sociálnej sfére a verbálne sa dožadovali napĺňania idey sociálneho štátu, ale v určitých momentoch nechceli alebo nevedeli pochopit, že práve ludácky režim je príčinou daného stavu. Aj za takéhoto stavu sa však odbory postupne stali nežiaducim elementom. V prvej fáze svojho pôsobenia tak boli odbory v Slovenskom štáte (a už počas druhej republiky) vystavené, oproti predchádzajúcim demokratickým pomerom, procesu silnej transformácie, ktorá smerovala ku ich kontrole a ideologickej monopolizácii, ale aj napriek tomu vo vzţahu k režimu zohrávali do istej miery rolu semiopozície. ${ }^{111}$ To nebolo akceptovatelné po nástupe slovenského národné-

107 Slovenský robotnik, 25. januára 1943. Mikula vo svojich spomienkach píše: „Problémy u nás sa neriešili štrajkami ani demonštráciami, ale vzájomnou spoluprácou zamestnávatelov i zamestnancov. Vo vedení podnikov, v správnych radách, zasadali spolu s riaditel’mi i zástupcovia robotnikov. Všade bol elán i radost’ z práce. "Pozri Mikula, J.: Cesta, s. 34 .

108 Pre ročné zhodnotenie aktivity pozri Slovenský robotník, 13. január 1944.

109 SNA, Ministerstvo vnútra 1938-1945, kart. 703, inv. č. 1600/g-k2.

110 K problematike vyšlo pred rokom 1989 viacero publikácií, napr. Tomek, František: Revolučné odborové hnutie na Slovensku v revolúcii 1944-1948. Bratislava 1988, 169 s.

111 V literatúre sa konkrétne pre pozíciu krestanských odborov použil pojem „legálna opozícia.“ Pozri Pleva, J. - Tichý, M.: Krestanské, s. 122. Tento termín, ktorý minimálne v sociálnej sfére považovat za adekvátny, prebral aj Katuninec. Pozri Katuninec, M.: Charakter, s. 718. Podobná termín semiopozícia má aj teoretické ukotvenie, a to v kontexte rozlíšenia autoritárskeho a totalitného režimu. Semiopozičné skupiny sa čiastočne angažujú v kritike autoritárskeho prostredia, avšak s režimom fakticky spolupracujú bez požiadavky na podstatné zmeny. Takisto nekritizujú vodcov a akceptujú tradičnú legitímnost̉ či nevyhnutnost̉ podoby režimu. 
ho socializmu, ked' po vzostupe radikálneho krídla HSL'S začali ludácki politici aplikovat politickú prax inšpirovanú nacistickými vzormi. Odbory zakrátko z hladiska svojej činnosti de facto zanikli, aj ked' proces zániku de iure trval dlhšie. Po vzore NFP vznikla nová organizácia pracujúcich, Slovenská pracujúca pospolitost', ktorej činnosṫ však už bola obmedzená len na ideologické pôsobenie a udržiavanie sociálneho zmieru. O zlepšovaní životov pracujúcich na báze ich organizovaných aktivít už nemožno vôbec hovorit.

V Taliansku sa odborová otázka riešila pozvolne. Ešte niekolko rokov po uchopení moci fašistami jestvovali aj nefašistické odbory, hoci pluralitné prostredie už bolo obmedzené. Zlom nastal v roku 1925, ked' sa fašistické odbory stali jedinými legálnymi a vláda zrušila právo na štrajk. Fašistické odbory d'alej fungovali obmedzene v mantineloch režimu sociálneho korporativizmu do ktorého boli inkorporované. Ich vplyv bol však v zmysle reálneho zastupovania záujmov pracujúcich slabý a činnoste silne limitovaná. Tieto reálie sa podobajú vývinu na Slovensku od jesene 1938 do leta 1940. Ludáci videli vo fašistickom systéme inšpiráciu, čo sa prejavilo najmä v recepcii korporativistických myšlienok. Odbory takisto zostali zachované, čo je v kontraste s prístupom nacionálneho socializmu. Zhodný aspekt $\mathrm{v}$ podobe zachovania odborov, hoc prorežimných, spočíval aj $\mathrm{v}$ tom, že $\mathrm{v}$ istom čase sa stali platformou pre ilegálne aktivity najmä komunistických odbojových síl. Vývoj na Slovensku mal však aj svoje špecifiká. Išlo najmä o značný vplyv krestanských sociálnych encyklík, ktoré boli silnou inšpiráciou najmä pre politikov umierneného krídla HSLS, vrátane odborárov.

Nemeckí národní socialisti prišli s vlastnou koncepciou Volksgemeinschaft, akejsi 'beztriednej' nacionalistickej spoločnosti, v ktorej mali byt integrované všetky spoločenské vrstvy, vrátane robotníckej triedy. Odbory nacisti zlikvidovali hned' po uchopení moci. Namiesto nich vznikol Nemecký front práce, ktorý na pracujúcich pôsobil ideologicky a využíval aj sociálnu demagógiu. V jeho rámci vznikali rôzne podskupiny, ktoré sa snažili kontrolovat a riadit každý aspekt života pracujúcich, vrátane volného času. ${ }^{112}$ Takýto systém bol aplikovaný aj v Slovenskom štáte od roku 1942, hoci proces, vrátane obmedzenia a likvidácie dovtedy pôsobiacich ludáckych krestanských odborov, bol spustený už skôr.

Ked'sa vnútorná dynamika skúmaných diktátorských režimov vyvíjala pomyselným smerom k „totalite“ a nastala väčšia snaha o kontrolu hospodárstva a spolkového života, malo to negatívny, a od istého momentu až likvidačný vplyv na slobodné, resp. existenčné pôsobenie odborových organizácií. Vo všetkých troch skúmaných prípadoch sa dá vysledovat pôsobenie zamestnávatel'ských štruktúr v prospech pacifikácie kolektívnych záujmov pracujúcich a ich organizácii (odborov). Vo všeobecnosti možno konštatovat, že diktátorské režimy sledovali ciel ukončenia triedneho boja a sociálnych nepokojov. Chceli zabezpečit subordináciu pracujúcej triedy v prospech záujmov štátu. Okrem eliminácie odborovej slobody a ideologickej indoktrinácie pracujúcich, režimy pristúpili aj k regulácii pracovného trhu cez vládne určovanie cien a rôzne druhy represií.

112 Pre porovnanie, v nacistickom Nemecku Radostou k sile, v Slovenskom štáte Radostou k práci. 


\section{Transformation or extirpation? Development of trade unions in the Slovak state (1939-1945) in the context of selected European dictatorships}

The article deals with the question whether the changes that the Slovak trade union movement has affected (during the Slovak state 1939-1945) can be described as its transformation or rather the extinction. The research is done in a comparative context of trade unions and social policies of fascist Italy and Nazi Germany. When the internal dynamics of the examined dictatorial regimes evolved in a pioneering direction towards "totalitarianism" and a greater effort was made to control the economy and the society, it had it negative, and from a certain moment a liquidation effect on the existence of trade unions. In all three cases, the employers' structures can be traced in favor of pacifying the collective interests of workers and their organization. In general, dictatorial regimes have been pursuing the goal of ending class struggle and social unrest. They wanted to ensure the subordination of the working class to the interests of the state. In addition to the elimination of trade union freedom and ideological indoctrination of workers, the regimes also came to regulate the labor market through government pricing and various types of repression. In some point, only legally Christian trade union in Slovak stat were destroyed and replaced by new type of workers organization. But the new organization had only ideological impact and her primary role was to maintain social peace without real organization of working class. 